\title{
Rheology Enhancement for Remediated PX6 Melter Feed
}

by

J. C. Marek

Westinghouse Savannah River Company

Savannah River Site

Aiken, South Carolina 29808

R. E. Eibling

DOE Contract No. DE-AC09-89SR18035

This paper was prepared in connection with work done under the above contract number with the U.S.

Department of Energy. By acceptance of this paper, the publisher and/or recipient acknowledges the U.S: Government's right to retain a nonexclusive, royalty-free license in and to any copyright covering this paper, along with the right to reproduce and to authorize others to reproduce all or part of the copyrighted paper. 


\section{DISCLAIMER}

Portions of this document may be illegible in electronic image products. Images are produced from the best available original document. 


\section{DISCLAIMER}

This report was prepared as an account of work sponsored by an agency of the United States Government. Neither the United States Government nor any agency thereof, nor any of their employees, makes any warranty, express or implied, or assumes any legal liability or responsibility for the accuracy, completeness, or usefulness of any information, apparatus, product, or process disclosed, or represents that its use would not infringe privately owned rights. Reference herein to any specific commercial product, process, or service by trade name, trademark, manufacturer, or otherwise does not necessarily constitute or imply its endorsement, recommendation, or favoring by the United States Government or any agency thereof. The views and opinions of authors expressed herein do not necessarily state or reflect those of the United States Government or any agency thereof.

This report has been reproduced directly from the best available copy.

Available to DOE and DOE contractors from the Office of Scientific and Technical Information, P.O. Box 62, Oak Ridge, TN 37831; prices available from (615) 576-8401.

Available to the public from the National Technical Information Service, U.S. Department of Commerce; 5285 Port Royal Road, Springfield, VA 22161. 


\author{
CC: J. F. Ortaldo, 704-S \\ E. W. Holtzscheiter, 773-A \\ M. J. Plodinec, 773-A \\ W. G. Ramsey, 773-A \\ C. T. Randall, 704-T \\ E. K. Hansen, 676-15T \\ N. D. Hutson, 704-1T \\ D. H. Miller, 704-1T \\ M. E. Smith, 704-1T \\ C. W. Hsu, 704-1T \\ G. L. Gill, 704-1T \\ SRTC-PTD File
}

October 7, 1994

To: $\quad$ L. F. Landon, 704-T

D. A. Crowley, 704-1T

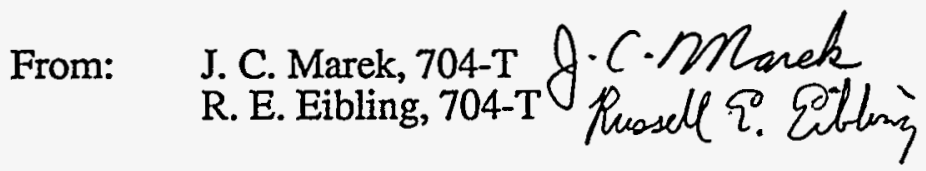

\title{
Rheology Enhancement for Remediated PX6 Melter Feed (U)
}

\section{Introduction}

IDMS PX6 was remediated by adding $30 \mathrm{wt} \%$ aluminum nitrate $\left(\mathrm{Al}\left(\mathrm{NO}_{3}\right)_{3}\right)$ solution to the PX6 melter feed to achieve an amount of aluminum equivalent to $0.87 \mathrm{~g}$. per $100 \mathrm{~g}$. melter feed. This is equivalent to adding $1.64 \mathrm{~g}$. of $\mathrm{Al} 2 \mathrm{O} 3$ per $100 \mathrm{~g}$. of melter feed. The remediation corrected the deficiency of aluminum in the feed, but as a side-effect reduced the $\mathrm{pH}$ and insoluble solids concentration, rendering the rheological properties of the feed unsuitable for maintaining frit suspension. The aluminum nitrate addition also rendered the feed highly oxidizing, with the parameter F-N (formate minus nitrate) currently estimated to be -1.9 in the remediated DMS feed material.

We recommend a chemical addition of $1.89 \mathrm{ml} 50 \mathrm{wt} \%$ caustic $(\mathrm{NaOH})$ solution per kilogram of IDMS PX6 melter feed to enhance the rheological properties of the material for suspending frit. We also recommend that the IDMS melter feed tank contents be sampled after the caustic treatment to confirm the chemical composition will produce acceptable glass and to characterize the solids concentration, $\mathrm{pH}$, and rheological properties of the material. This memorandum summarizes results of experimental work performed on the original IDMS PX6 melter feed, the remediated IDMS PX6 melter feed, and melter feeds produced in a laboratory simulation to duplicate the DMS remediation as well as the experimental results on the caustic treatment to enhance the rheology. Characterization of the products of excess caustic addition and what steps to take if excess caustic is inadvertently added to the IDMS PX6 melter feed are also discussed. 


\section{Summary of Conclusions}

The following are the main conclusions from this work:

1) The remediation of IDMS melter feed with $30 \mathrm{wt} \%$ aluminum nitrate solution caused the material to thin and the disappearance of a detectable yield stress.

2) Duplication of the remediation strategy in the laboratory produced the same shift in rheological properties of the IDMS PX6 feed.

3) Samples of the remediated IDMS PX6 feed and the material produced in the laboratory duplication of the aluminum nitrate remediation foam when shaken vigorously (high shear). The foam is relatively stable, taking about 30 minutes to disappear.

4) The rheological properties were restored by adding $1.89 \mathrm{ml} 50 \mathrm{wt} \%$ caustic $(\mathrm{NaOH})$ solution per kilogram of IDMS PX6 melter feed. This result was obtained in an initial test performed 9/12/94 and duplicated in a followup test performed 9/29/94. Analyses of glass samples prepared by vitrifying this sample in a crucible indicated the remediated IDMS PX6 melter feed will produce acceptable glass (within $\pm 5 \%$ of the PCCS targets). The caustic treatment did not change the tendency of the material to foam when shaken.

5) A slow formic acid denitration reaction is probably occurring in the remediated IDMS PX6 melter feed, as evidenced by a pungent odorous gas that vented when the sample container was opened to perform the duplicate caustic treatment.

6) Addition of $2.75 \mathrm{ml} 50 \mathrm{wt} \%$ caustic (NaOH) solution per liter of DMS PX6 melter feed caused the rheological properties to thicken excessively, indicating excessive caustic had been added. The yield stress of this material approached $250 \mathrm{dynes} / \mathrm{cm}^{2}$.

7) The rheological properties after excess caustic addition were recoverable (thinned) by diluting the feed with water.

8) Addition of concentrated nitric acid produced shifts in the rheological properties of the DMS PX6 feed similar to the remediation with aluminum nitrate solution.

\section{Experimental}

A sample of the original, unremediated DMS PX6 melter feed was provided by W. G. Ramsey of the DWPT Glass Technology Group (GTG) for characterization and experimental use in duplicating the $\mathrm{Al}\left(\mathrm{NO}_{3}\right)_{3}$ remediation performed in the IDMS Melter Feed Tank. A sample of the remediated DMS melter feed (ID-PX6-MFTR-7487) was provided by the DWPT Large Scale Experimentation Group (LSEG) for experimental use in developing methods to enhance the rheological properties. The materials were analyzed for $\mathrm{pH}$ and solids concentration. Rheological characterization of the materials was performed using a HAAKE Rotovisco RV20 rheometer. The RV20 utilizes the Searle method (concentric cylinders with inner cylinder rotating) to determine the rheological flow curve (shear stress versus shear rate plot) from torque measurements. Rheograms were obtained at $25^{\circ} \mathrm{C}$ over a range of shear rates of from $0-350 \mathrm{sec}^{-1}$ by increasing the shear rate from 0 to $350 \mathrm{sec}^{-1}$ in 5 minutes, holding at $350 \mathrm{sec}^{-1}$ for 0.1 minute, and decreasing the shear rate from 350 to $0 \mathrm{sec}^{-1}$ in 5 minutes. The rheological 
properties were modeled as Bingham fluids to allow comparisons between the various materials and with DWPF materials.

\section{Results}

Figure 1 depicts rheograms for three materials of interest: the unremediated IDMS PX6 melter feed (before aluminum nitrate treatment) sent to TNX by Ramsey, the remediated PX6 melter feed (post-aluminum nitrate treatment), and the remediated PX6 melter feed after the caustic treatment, which restored the rheological properties essentially to those of the unremediated starting material. More detailed results are as follows:

Unremediated IDMS PX6 Melter Feed: Figure 1 depicts the rheological flow curve obtained for the unremediated IDMS PX6 melter feed (before aluminum nitrate treatment) sent to TNX by Ramsey. The Bingham fluid parameters for the increasing shear rate curve are yield stress $=68.4 \mathrm{dynes} / \mathrm{cm}^{2}$ and consistency $=21.7 \mathrm{cp}$. The unremediated feed was analyzed at $45.82 \mathrm{wt} \%$ total solids, $35.02 \mathrm{wt} \%$ insoluble solids, and $\mathrm{pH}=8.27$, all of which are typical of DMS melter feeds produced with simulated sludge feed containing noble metals.

Remediated PX6 Melter Feed: Figure 1 depicts the rheological flow curve at $50^{\circ} \mathrm{C}$ obtained 8/22/94 for sample ID-PX6-MFTR-7484, the remediated PX6 melter feed (postaluminum nitrate treatment). The material behaves essentially like a Newtonian fluid, with no yield stress. The Bingham fluid parameters for the increasing shear rate curve reduce to viscosity $=10.5 \mathrm{cp}$ and zero yield stress. These properties are not typical of IDMS melter feeds produced with noble metals in the simulated sludge feed.

Proper Caustic Adjustment of PX6 Melter Feed: Figure 1 depicts the rheological flow curve obtained for material produced by adding $0.8 \mathrm{ml}$ of $50 \mathrm{wt} \%$ caustic to $422.4 \mathrm{~g}$. of remediated $\left(\mathrm{Al}\left(\mathrm{NO}_{3}\right)_{3}\right.$-treated) ID-PX6-MFTR-7487 melter feed on 9/12/94. The $\mathrm{pH}$ was determined to rise from 3.4 to 3.91 as a result of the caustic treatment. The Bingham fluid parameters are yield stress $=52.4$ dynes $/ \mathrm{cm}^{2}$ and consistency $=40 \mathrm{cp}$. The caustictreated feed was analyzed at $37.86 \mathrm{wt} \%$ total solids, $13.65 \mathrm{wt} \%$ insoluble solids, and $\mathrm{pH}=3.94$.

A followup test was performed 9/29/94 by adding $1.1 \mathrm{ml}$ of $50 \mathrm{wt} \%$ caustic to $584.5 \mathrm{~g}$. of remediated $\left(\mathrm{Al}\left(\mathrm{NO}_{3}\right)_{3}\right.$-treated) ID-PX6-MFTR-7487 melter feed. A pungent gas vented from the container of remediated IDMS PX6 feed. when it was opened to perform the duplicate caustic treatment. The gases were likely the result of a slow formic acid denitration reaction, which is also indicated from a reduction of the formate content of the to material from $>20,000 \mathrm{mg} / \mathrm{L}$ to about $2000 \mathrm{mg} / \mathrm{L}$. The Bingham fluid parameters for the increasing shear rate curve were yield stress $=45.2$ dynes $/ \mathrm{cm}^{2}$ and consistency $=43.8$ $\mathrm{cp}$, which agree with the parameters determined in the earlier test. The caustic-treated feed was analyzed at $47.58 \mathrm{wt} \%$ total solids and $\mathrm{pH}=4.11$. Analyses of glass samples prepared by vitrifying the remediated IDMS PX 6 melter feed in a crucible are shown in Table 1. The results indicate the remediated IDMS PX6 melter feed will produce acceptable glass after the caustic treatment to modify the rheological properties. The primary frit elements (potassium, silicon, and boron) and primary waste oxides are within $\pm 5 \%$ of the PCCS targets.

Lab Simulation of IDMS PX6 Remediation: Figure 2 depicts the rheological flow curve at $25^{\circ} \mathrm{C}$ of material produced in the laboratory to duplicate the remediation of the IDMS PX6 melter feed. The rheogram of the remediated DMS PX6 feed is also shown, for comparison. The laboratory simulation was performed by adding $172 \mathrm{ml}$ of the $30 \mathrm{wt} \%$ 
aluminum nitrate solution used in the IDMS remediation to $500 \mathrm{ml}$ of the unremediated IDMS PX6 feed sent to TNX by Ramsey. The material also behaves essentially like a Newtonian fluid, with no yield stress. The Bingham fluid parameters for the increasing shear rate curve reduce to viscosity $=8.85 \mathrm{cp}$ and zero yield stress. The lab-remediated feed was analyzed at $38.02 \mathrm{wt} \%$ total solids, $15.35 \mathrm{wt} \%$ insoluble solids, and $\mathrm{pH}=3.37$.

Excess Caustic Adjustment of PX6 Melter Feed: Figure 3 depicts the rheological flow curve obtained for material produced by adding $0.55 \mathrm{ml}$ of $50 \mathrm{wt} \%$ caustic to $200 \mathrm{ml}$ of remediated $\left(\mathrm{Al}\left(\mathrm{NO}_{3}\right)_{3}\right.$-treated) ID-PX6-MFTR-7487 melter feed. Immediately after the treatment, the $\mathrm{pH}$ was determined to be 4.68. The Bingham fluid parameters for the increasing shear rate curve are yield stress $=244$ dynes $/ \mathrm{cm}^{2}$ and consistency $=25.5 \mathrm{cp}$. The excess caustic-treated feed was analyzed at $32.9 \mathrm{wt} \%$ total solids, $9.03 \mathrm{wt} \%$ insoluble solids, and $\mathrm{pH}=4.17$. The rheological parameters exceed the DWPF design bases.

Mitigating Excess Caustic Adjustment: Figure 3 also depicts the rheological flow curve obtained for material produced by adding $12.0 \mathrm{~g}$. deionized water to $47.9 \mathrm{~g}$. of the excess caustic-treated material prepared as described above. Immediately after the treatment, the $\mathrm{pH}$ was determined to be 4.68. The Bingham fluid parameters for the increasing shear rate curve are yield stress $=43.2$ dynes $/ \mathrm{cm}^{2}$ and consistency $=50.6 \mathrm{cp}$. The diluted excess caustic-treated feed was analyzed at $26.7 \mathrm{wt} \%$ total solids, $8.17 \mathrm{wt} \%$ insoluble solids, and $\mathrm{pH}=4.30$.

Nitric Acid Remediation Tests: Figure 4 depicts rheograms of the unremediated IDMS PX6 melter feed after treatment with concentrated ( $70 \mathrm{wt} \%$ ) nitric acid. Rheograms of the unremediated and remediated IDMS PX6 melter feeds are also shown for comparison. Addition of $20 \mathrm{ml}$ of $70 \mathrm{wt} \%$ nitric acid to $678.3 \mathrm{~g}$. of unremediated IDMS PX6 melter feed $\left(29.5 \mathrm{ml} / \mathrm{kg}\right.$ feed) reduced the rheological properties to yield stress $=25$ dynes $/ \mathrm{cm}^{2}$ and consistency $=9 \mathrm{cp}$. In a followup test, addition of $43 \mathrm{ml}$ of $70 \mathrm{wt} \%$ nitric acid to $693.0 \mathrm{~g}$. of unremediated IDMS PX6 melter feed $(62 \mathrm{ml} / \mathrm{kg}$ feed $)$ reduced the rheological properties to zero yield stress and viscosity $=8.85 \mathrm{cp}$, indicating that nitric acid addition is capable of producing essentially the same shifts in the rheological characteristics as occurred in the aluminum nitrate remediation.

\section{Quality Assurance}

The experimental procedures and observations are recorded in laboratory notebooks WSRC-NB-93-35 assigned to J. C. Marek and WSRC-NB-90-131 assigned to R. E. Eibling. All samples were provided with a unique identifier to facilitate tracking and data basing of results. The accuracy of all analytical measurements was controlled with check standards that were controlled to within $5 \%$ of their nominal values. The analytical results are stored in the Laboratory Information Management System (LIMS) on the TNX VAX computer in 679-T. 
Table 1. Analysis of Vitrified Sample After Caustic Treatment to Modify Rheology of Remediated IDMS PX6 Melter Feed

Element

$\mathrm{Al}$

B

$\mathrm{Ba}$

$\mathrm{Cr}$

Cs

$\mathrm{Cu}$

$\mathrm{Fe}$

$\mathrm{K}$

$\mathrm{Li}$

$\mathrm{Mg}$

$\mathrm{Mn}$

$\mathrm{Na}$

$\mathrm{Ni}$

$\mathrm{P}$

$\mathrm{Si}$

$\mathrm{Sr}$

$\mathrm{Ti}$

$\mathrm{Zn}$

$\mathrm{Zr}$
Analytical Values, wt\% ICP/MW ICP/Na2O2

2.708

2.567

0.069

0.596

0.068

0.194

6.650

2.370

0.871

1.320

7.710

0.705

0.000

0.145

0.014

0.082

0.081

0.625
Average Target

wt\% Values, wt\% \% from Target

2.708

2.567

0.069

0.596

0.068

0.194

6.690

2.370

2.193

0.895

1.320

7.710

0.705

0.000

0.145

23.50

0.014

0.083

0.081

0.625
2.765

2.601

0.069

0.591

0.089

0.177

6.768

2.354

2.354

0.896

1.300

7.290

0.699

0.000

0.128

24.46

0.010

0.079

0.069

0.719
$-2.07$

$-1.30$

0.06

0.83

$-23.3$

9.41

$-1.15$

0.66

$-6.86$

$-0.22$

1.51

5.76

0.80

0.000

13.22

$-3.93$

42.12

4.68

17.46

$-13.09$ 
Figure 1.

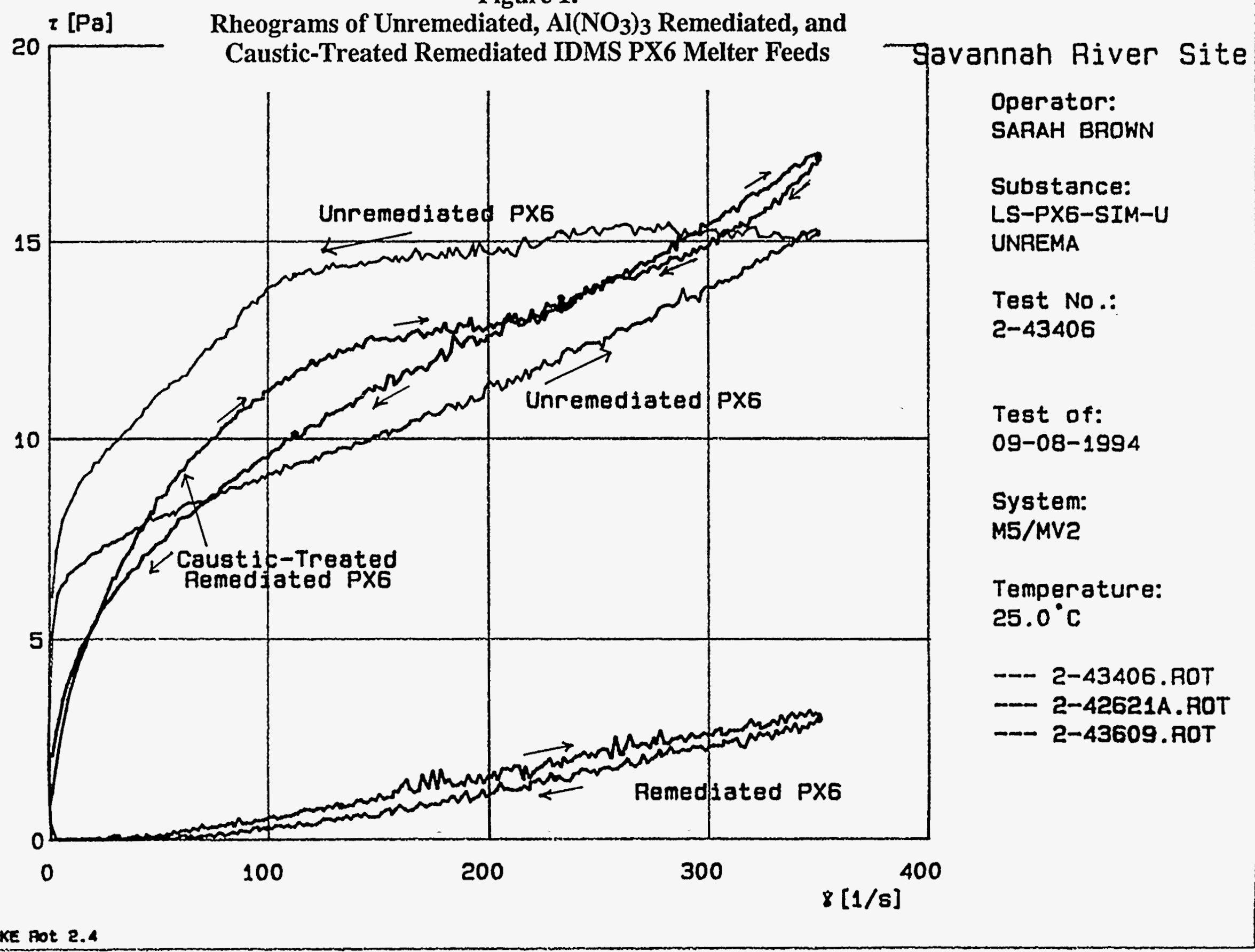


Figure 2.

I [Pa] Rheograms Comparing Remediated DMS PX6 Melter Feed

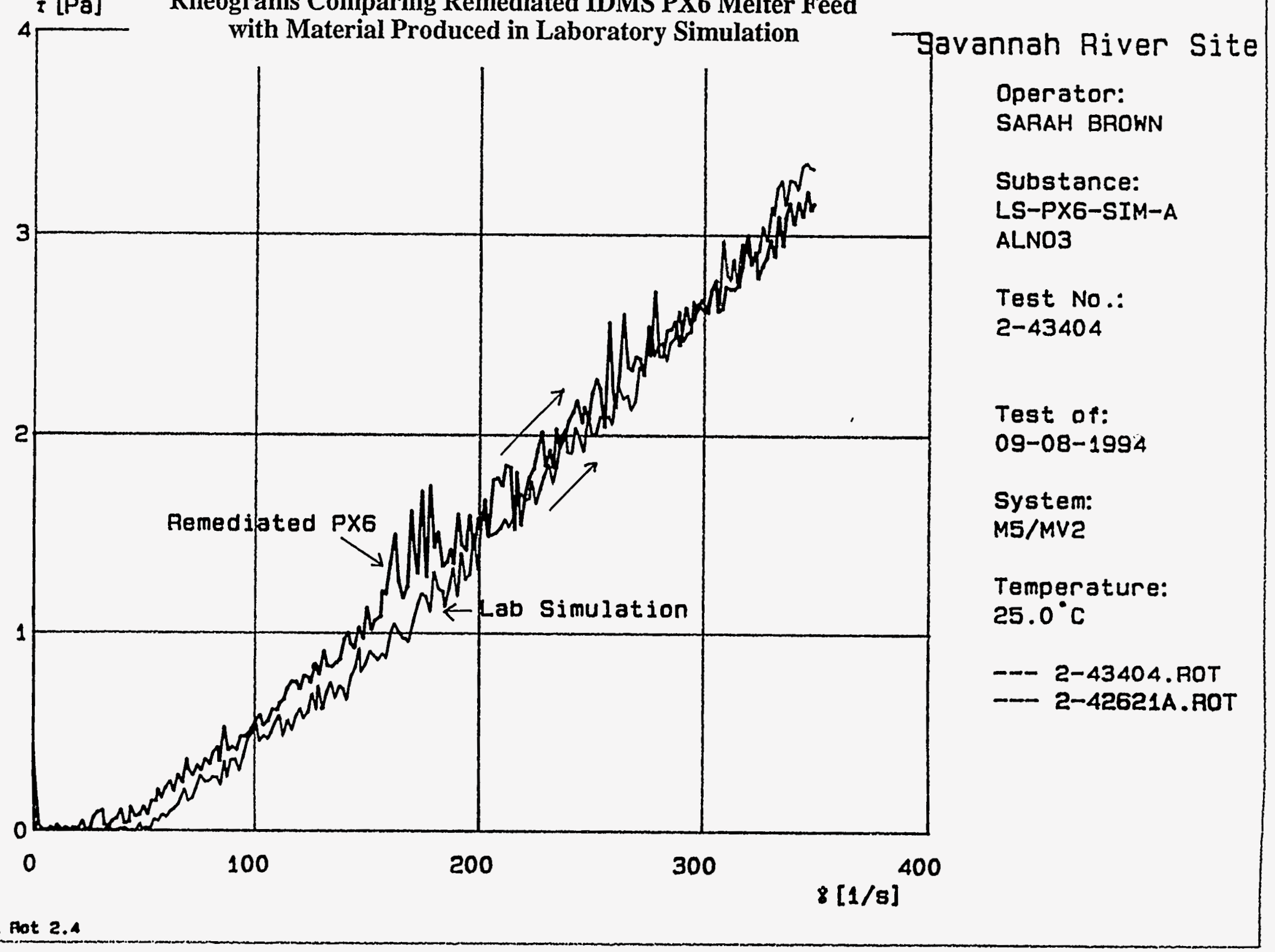


Figure 3.

Rheograms of Remediated IMDS PX6 Melter Feed

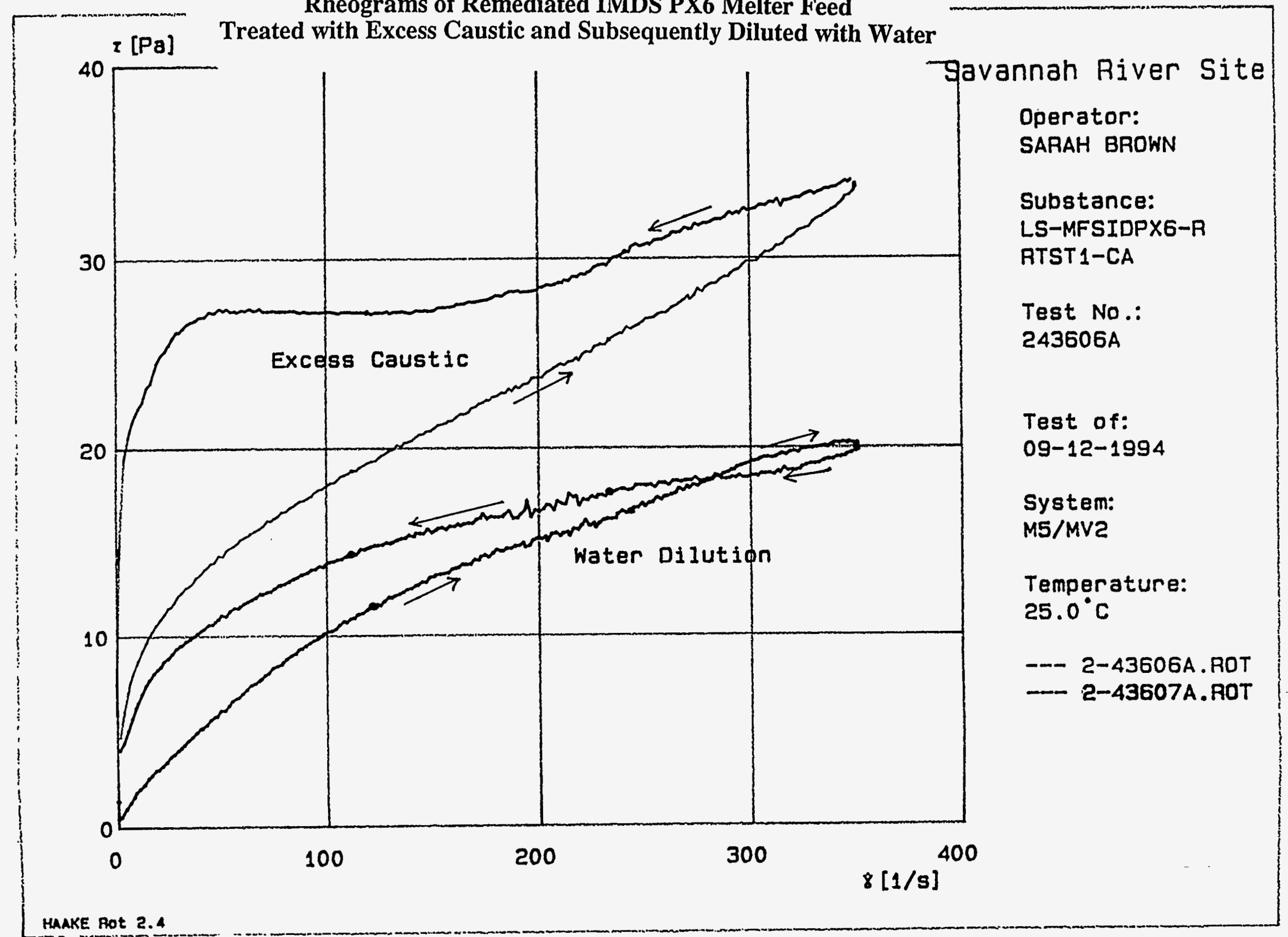

HAAKE ROT 2.4 
Figure 4.

Rheograms Comparing Nitric Acid Treatments with

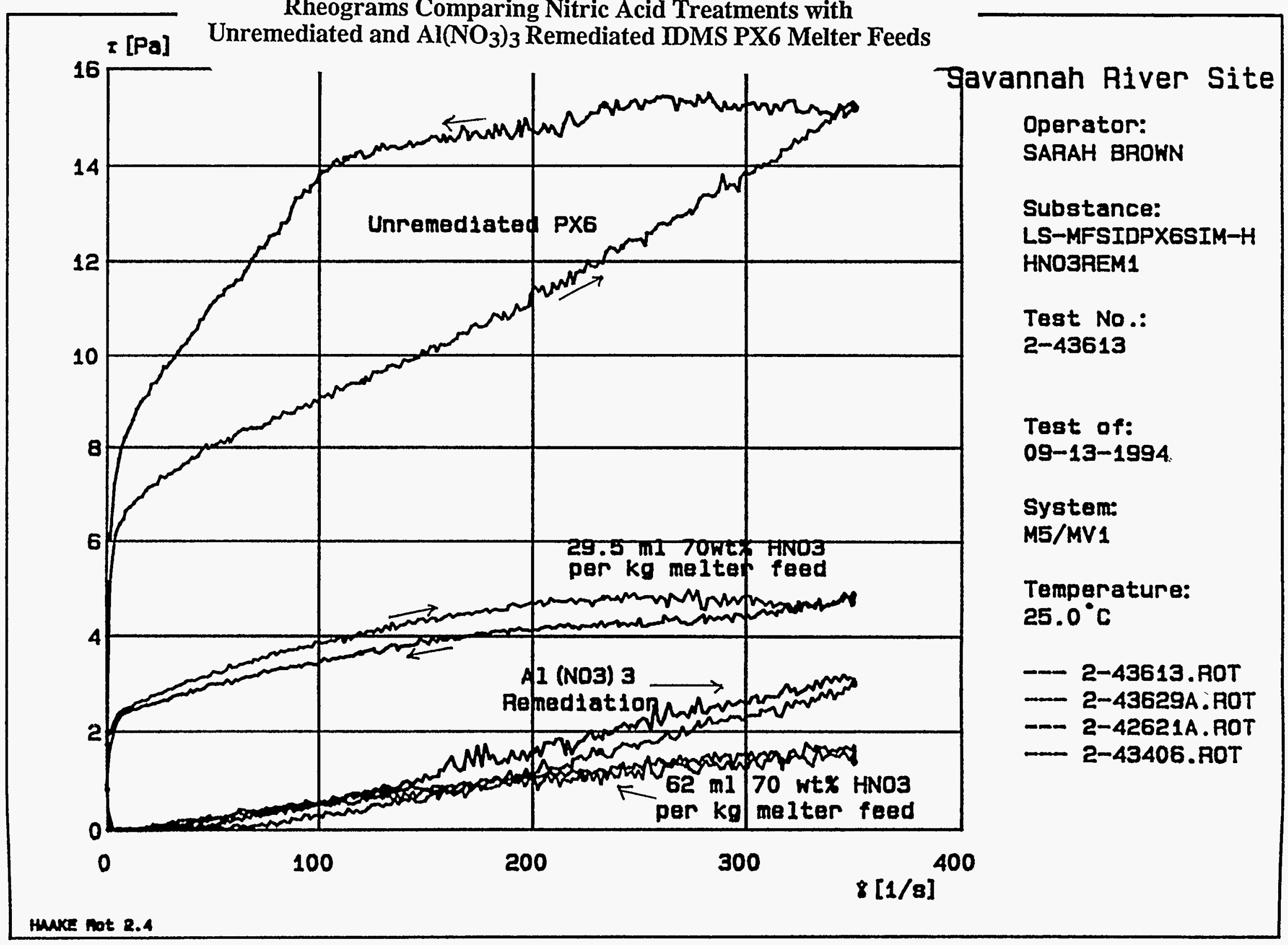

